\title{
IIIISGUCDERGI.ORG
}

"IȘ, GÜç̣" ENDÜSTRi iLIȘKiLERi VE INSAN KAYNAKLARI DERGISi

"IS, GUC" INDUSTRIAL RELATIONS AND HUMAN RESOURCES JOURNAL

\section{Predicting Work Attitudes and Turnover Intentions Among Officers: The Importance of Adlerian Personality Attributes}

\author{
Justina Liesiené, \\ Auksè Endriulaitienè, \\ Loreta Bukšnytè, \\ Loreta Gustainienè, \\ Roy Kern \\ Vytautas Magnus University, Kaunas
}

Nisan/April 2010, Cilt/Vol: 12, Say1/Num: 2, Page: $41-58$ ISSN: 1303-2860, DOI: 10.4026/1303-2860.2010.142.x

Makalenin on-line kopyasına erişmek için:

http://www.isguc.org/?p=article\&id=413\&vol=12\&num=1\&year=2010

To reach the on-line copy of article:

http://www.isguc.org/?p=article\&id=413\&vol=12\&num=1\&year=2010

Makale İçin İletişim/Correspondence to: 
(C) 2000- 2010

"İşGüç" Endüstri İlişkileri ve İnsan Kaynakları Dergisi

"İşGüç" Industrial Relations and Human Resources Journal

Nisan/April 2010, Cilt/Vol: 12, Say1/Num: 2

ISSN: 1303-2860, DOI: 10.4026/1303-2860.2010.142.x

Editör/Editor-in-Chief

Aşkın Keser (Kocaeli University)

Editör Yardımcıları/Co-Editors

K.Ahmet Sevimli (Uludă̆ University)

Gözde Yılmaz (Kocaeli University)

Uygulama/Design

Yusuf Budak (Kocaeli Universtiy)

\author{
Yayin Kurulu / Publishing Committee \\ Dr.Zerrin Firat (Uludăg University) \\ Doç.Dr.Aşkın Keser (Kocaeli University) \\ Prof.Dr.Ahmet Selamoğlu (Kocaeli University) \\ Yrd.Doç.Dr.Ahmet Sevimli (Uludağ University) \\ Yrd.Doç.Dr.Abdulkadir Şenkal (Kocaeli University) \\ Yrd.Doç.Dr.Gözde Yılmaz (Kocaeli University) \\ Dr.Memet Zencirkıran (Uludağ University)
}

Uluslararası Danışma Kurulu / International Advisory Board Prof.Dr.Ronald Burke (York University-Kanada)

Assoc.Prof.Dr.Glenn Dawes (James Cook University-Avustralya)

Prof.Dr.Jan Dul (Erasmus University-Hollanda)

Prof.Dr.Alev Efendioğlu (University of San Francisco-ABD)

Prof.Dr.Adrian Furnham (University College London-İngiltere)

Prof.Dr.Alan Geare (University of Otago- Yeni Zellanda)

Prof.Dr. Ricky Griffin (TAMU-Texas AEM University-ABD)

Assoc. Prof. Dr. Diana Lipinskiene (Kaunos University-Litvanya)

Prof.Dr.George Manning (Northern Kentucky University-ABD)

Prof. Dr. William (L.) Murray (University of San Francisco-ABD)

Prof.Dr.Mustafa Özbilgin (University of East Anglia-UK)

Assoc. Prof. Owen Stanley (James Cook University-Avustralya)

Prof.Dr.Işık Urla Zeytinoğlu (McMaster University-Kanada)

Danışma Kurulu / National Advisory Board

Prof.Dr.Yusuf Alper (Uludağ University)

Prof.Dr.Veysel Bozkurt (Uludağ University)

Prof.Dr.Toker Dereli (Işık University)

Prof.Dr.Nihat Erdoğmuş (Kocaeli University)

Prof.Dr.Ahmet Makal (Ankara University)

Prof.Dr.Ahmet Selamoğlu (Kocaeli University)

Prof.Dr.Nadir Suğur (Anadolu University)

Prof.Dr.Nursel Telman (Maltepe University)

Prof.Dr.Cavide Uyargil (İstanbul University)

Prof.Dr.Engin Yildırım (Sakarya University)

Doç.Dr.Arzu Wasti (Sabancı University)

Dergide yayınlanan yazılardaki görüşler ve bu konudaki sorumluluk yazarlarma aittir.

Yayınlanan eserlerde yer alan tüm içerik kaynak gösterilmeden kullanılamaz.

All the opinions written in articles are under responsibilities of the outhors.

None of the contents published can't be used without being cited. 


\title{
Predicting Work Attitudes and Turnover Intentions Among Officers: The Importance of Adlerian Personality Attributes
}

\author{
Justina Liesienè, \\ Auksė Endriulaitienè, \\ Loreta Bukšnytè, \\ Loreta Gustainienè, \\ Roy Kern \\ Vytautas Magnus University, Kaunas
}

\begin{abstract}
:
This study investigated the predictive value of Adlerian personality attributes related to work attitudes and turnover intentions in a sample of 227 prison officers. The assessment instruments employed in the study included the Basic Adlerian Scales for Interpersonal Success Adult Form. Spector's Job Satisfaction questionnaire, Meyer and Allen's Organizational Commitment scale and four questions designed to assess work motivation and attitudes. Employee turnover intentions were assessed with a three item scale. The results revealed significant relationship with personality attributes, work attitudes and turnover intentions. Intention to leave the job could be predicted by job satisfaction organizational commitment and personality attributes, but not by work motivation.
\end{abstract}

Keywords: Adlerian lifestyle; BASIS-A, job satisfaction, organizational commitment, work motivation, turnover intention 


\section{Introduction}

Researchers have identified a connection between selected personality attributes, work attitudes, job satisfaction, organizational commitment and work motivation (Liesiene and Endriulaitiene, 2008, Geneviciute-Janoniene and Endriulaitiene, 2008; Bowling, 2007; Tyler and Newcombe, 2006; Latham and Pinder, 2005; Judge and Ilies, 2002; Jong et al., 2001). In addition researchers have explored the impact of work attitudes and turnover intentions with a variety of work settings and in particular prison settings (Labatmediene et al., 2007; Dowden and Tellier, 2004; Byrd et al., 2000; Wright, 1993). At this time there are no studies that specifically address the organizational variables of work attitudes, personality, and turnover intentions of correctional officers in the country of Lithuania. Officers in correctional institutions in Lithuania as well as other countries work in very stressful and restrictive settings which contribute to a high incidence of turnover of staff. Those who focus on research in the area of correctional settings encourage others to conduct research related to the organizational variables that lead to job dissatisfaction and turnover in these settings (Castle, 2008; Dowden and Tellier, 2004; Lambert et al., 2004).

The purpose of this study was to explore the relationship of the Adlerian Psychology lifestyle personality attributes and the organizational variables of work motivation, job satisfaction, organizational commitment and turnover intentions of officers in a correctional institution in Lithuania.

\section{Personality, work and turnover}

Organizational commitment, job satisfaction and work motivation are some of the most popular work attitudes investigated by theorists and practitioners in organizational psychology. These work- related attitudes have been found to be associated with job performance (Wood and Beckmann, 2006; Barrick and Mount, 2005; Woodardet al.,
1994), intention to quit a job (Labatmediene et al., 2007; Mynatt et al., 1997) as well as increased job productivity (Baard et al., 2004). These work attitudes, as it relates to the present study, have been found to be associated with turnover among correctional officers (Dowden and Tellier, 2004; Byrd et al., 2000; Wright, 1993). Byrd et al, (2001) found job dissatisfaction was the strongest predictor of a detention officer's inclination to leave their job.

At the present, there is no agreement on the sequence of the relations and possible mediating effects of personality, work attitudes and job performance. Bowling (2007) questioned the predictive value of job satisfactions to performance, but proposed that employee personality may be of more benefit to explore related to work performance. Significant relation between personality and performance was found in studies conducted by Tyler and Newcombe (1996) and Mynatt et al. (1997). However Mynatt et al.(1997) were not able to find a relationship between personality and turnover intentions.

In relation to the present study with correctional officers there are two models that are proposed to possibly shed light on the variables that may account for job satisfaction and attrition. One model addresses individual and the other organizational factors (Castle, 2008). The individual model, with a focus on personality attributes, has been used to isolate the possible connections of work attitudes in organizational settings. Extensive studies have been conducted to assess the connection to the Big Five personality model with theses attitudes (Mount et al., 2006; Barrick and Mount, 2005; Judge and Ilies, 2002). This research has revealed significant relationships with the personality attributes of conscientiousness, emotional stability (Mount et al, 2006; Wood \& Beckmann, 2006; Lee et al., 2005; Barrick and Mount, 2005; Neubert, 2004; Judge and Ilies, 2002) openness to experience, extraversion and agreeableness with work perfor- 
mance (Wood \& Beckmann, 2006, Mount et al, 2006; Barrick \& Mount, 2005; Neubert, 2004; Jong, Velde \& Jansen, 2001; George \& Zhou, 2001). Positive relationships have been found between neuroticism and feeling of exhaustion and lower job satisfaction among the police officers (Ortega et al., 2006). Yali et al. (2004) revealed that personal-organizational fit and extraversion are the most significant indicators for job performance among sales people. Mynatt et al. (1997) detected the expected relationship between Type A personality and level of job satisfaction. In the research by Judge et al. (2000) self-evaluations measured in childhood and in early adulthood were linked to job satisfaction.

However, some question the value of assessing individual characteristics such as personality attributes and claim that these variable accounts for a small percentage of the total variance in relation to professional importance ratings and in levels of job satisfaction (Furnham et al., 2002). Some authors suggest that organizational variables should be included in future research to assess job satisfaction (Furnham et al., 2002; Koustelios, 2001). Other researchers propose climate variables (Griffin, 2001), gender (Blickle et al., 2006; Hausknecht et al., 2004; Bishay, 1996; Carlson and Latta, 1980) and age (Kanfer and Ackerman, 2000, Woodardet al., 1994) as organizational variable that may clarify work performance.

Other researchers who investigate personality structure and measurement are not convinced that results clearly identify the interrelatedness of the work variables under consideration (Ones et al., 2005). Bishay (1996) argued that the Big Five traits may be useful for some research on job performance but may fall short in the measurement of more concrete and narrow personality traits. Though there may be some disagreement the forgoing research does seem to support that individual personality variables need to be considered when conducting research on work attitudes. Still there is not sufficient ag- reement on which personality traits predict organizational behavior. Many authors emphasize the importance of the fit between personality and different job and organizational factors (Amos and Weathington, 2008; McCulloch and Turban, 2007; Ehrhart, 2006; Westerman and Cyr, 2004; Rentsch and McEwen, 2002; Furnham, 2001). However, clear answers as to which professions and which specific personality measures are most likely to predict performance is missing (Jenkins and Griffith, 2004). Possibly though the Big Five research has provided some answers there is still no clear model of the way personality attributes impact work behavior - directly or with the mediating effect of work attitudes such as organizational commitment, job satisfaction or work motivation. Possibly other comprehensive theoretical models related to personality need to be explored to extend our knowledge base related to the connection of personality and work attitudes variables. For this study the researchers have decided to use another theoretical model to address the interplay of personality and work attitudes. This model is based on the principles of Individual Psychology of Alfred Adler.

\section{Employing Individual Psychology in or- ganizational settings}

The rationale to use Individual Psychology as a theoretical base for the study and in particular the personality construct of lifestyle is based on the successful application in other organizational settings. A second reason is that writers in the field of Individual Psychology have identified the connection between the theory and organizational variables and that there is a psychometric instrument supported by a rich body of research to assess the personality attributes related to lifestyle.

\section{Overview of Individual Psychology appli- cation in organizations}

Individual psychology has proved its value in many fields: parenting, education, family 
therapy, group therapy, group counseling and art therapy and to a lesser degree work related attitudes (Ferguson, 2007). Watkins (1984) described a method of integrating the main constructs of Individual Psychology of lifestyle, social interest and early recollections with vocational behavior. Catlin (1984) used the Adlerian approach to describe a training model that could be implemented in organizations. Ferguson (1996) described the fit of democratic ideas of Individual Psychology and its' impact on the behavior, attitudes and motivations of leaders and followers. Kern and Peluso (1999) proposed parallels of Individual Psychology family constructs to organizational structures and organizational behavior. The principles of Adlerian life goals and other theories which include either goal setting or life tasks were addressed in the writing of Ferguson (2003). She also indicated the importance of the role lifestyle attributes should play in relation to dynamics in organizations. Carlson et al. (2007) emphasized the importance of the Individual Psychology construct of social interest operationalized in a technique the authors referred to as the E group technique (empathy, equality, encouragement, education, and empowerment) as a powerful intervention to increase individual effectiveness in organizational settings. They claim that these principles are related to such work attitudes as higher work motivation, job satisfaction and productivity. Application of principles of Individual Psychology in organization might improve the communication between peers, leaders and followers (Ferguson, 2007). Lemonides (2007) presented a detailed model of ways the principles of Individual Psychology are applicable to organizational settings related to training programs. A final study of importance was a study confirming the connection of lifestyle personality attributes and transformational leaders. The importance of this study was that it was the first reported research in Individual Psychology to support the relationship of personality and the organizational variable of leadership (Frey et al.)
This study highlights the potential of using the theoretical model of Individual Psychology in organization settings but also addresses a need to expand the use of the model in additional empirical studies related to organizational behavior.

\section{Adlerian approach: individual differences in the work place}

The importance of work was proposed by Adler, the founder of Individual Psycho$\operatorname{logy}$, as one of the three major life tasks. Adler proposed that all humans through out their life span are confronted with the challenges of the three major life task of friendship (social relationships), work (careers) and love relationships (Ansbacher and Ansbacher, 1956). All difficulties and challenges for humans are related to the problems that arise from one's struggles related to these three tasks. To address these tasks the individual at a very early age in the family of origin creatively selects a set of behaviors, beliefs and personality attributes to deal with the life task. Adler referred to this organized set of beliefs and behaviors as one's style of life or lifestyle (Suprina and Lingle, 2008; Lemonide, 2007; Ferguson, 2003; Ansbacher and Ansbacher, 1956). One's lifestyle may be viewed as a self imposed organized set of beliefs and personality attributes that an individual creates within the family which he or she uses to solve the problems that evolve from these three life task (Eskstein and Kern, 2009, Adler, 1969). This means that each individual regardless of the life task or problem applies this systematic model with in the family, love relationship or work setting. Consequently Stone (2007) saw work behavior as a solution of work task in person's life. White (2005) supports this idea by claiming that one's professional life can be seen as the continuation of the childhood expectations and lifestyle developed within these expectations. Some research on the lifestyle and work setting has been designed to measure these connections.

Early studies by Gentry et al.(1980), Magner- 
Harris et al.(1981) have found connections with lifestyle personality attributes and Holland's typologies of vocational preference. A few years later common lifestyle personality attributes were found among nurses (Biechekas and Neilon, 1983), among priests (Newlon and Mansager, 1986) and among a vocational types and lifestyle with the Lithuanian adolescents (Kepalaite et al, 2008). However, there are no research studies that have been reported in the professional literature to address the interrelatedness lifestyle personality attributes, job satisfaction, organizational commitment, work motivation and intentions to leave the job with correctional officers in the country of Lithuania.

\section{Reseach questions and purpose}

The purpose of this study is to investigate the interrelatedness of lifestyle, job satisfaction, organizational commitment, work motivation, and intentions to leave the job with a sample of correctional officers in a prison setting in Lithuania. More specifically the research questions to be explored are the following.

1. What is the relationship among Adlerian personality attributes, work attitudes and turnover intentions?

2. What is the predictive value of Adlerian personality attributes for work attitudes (job satisfaction, organizational commitment and work motivation)?

3. Which work attitudes (job satisfaction, organizational commitment or work motivation) or personality attributes are the best predictors for turnover intention?

\section{Methodology}

\section{Sample and research procedures}

227 officers from one correctional institution participated in the study. Participants were chosen following a collaboration contract between the faculty at Vytautas Magnus University and the organization. After ente- ring the primary data, it was determined that 205 participants completed all the inventories and demographic data for analysis purposes. 22 participants were deleted from the analysis due to incomplete completion of inventories or biographical data information. .

There were 172 (84\%) males and 31 (15\%) females. Participants ranged in age from 21 to $57(\mathrm{M}$ age $=36.16$ years, $\mathrm{SD}=8.228)$. The work tenure among employees ranged from 1 to $40(\mathrm{M}=14.94$ year, $\mathrm{SD}=8.51)$. They have been working in a current position on average for 7.59 years (from 0.09 to 31 year with a standard deviation 6.20).

\section{Measures}

The Basic Adlerian Scales for Interpersonal Success for Adults(BASIS-A) was used to assess the life style personality attributes of belonging- social interest a measure of empathy, gregariousness, and comfort with people (cronbach's alpha $=0.81$ ), going along a measure of rule focused and lack of rule focused behavior (cronbach's alpha $=0.81$ ), wanting recognition a measure of the importance of validation from others and being successful (cronbach's alpha $=0.78$ ), taking charge a measure of the need to control and direct others (cronbach's alpha $=0.72$ ), and the being cautious scale which is designed to assess hypervigilience and trust and mistrust related to family of origin (cronbach's alpha $=0.84)($ Wheeler et al.1993). The responses by the participants on the 65 item inventory are organized on a 5-point Likert scale ranging from 1 (strongly disagree) to 5 (strongly agree). Back-forward translation from English to Lithuanian language was completed by students and university personnel from another major university in Lithuania. The Cronbach's alpha for the full questionnaire for this study was 0.75 .

Job satisfaction was measured by Spector's Job Satisfaction questionnaire (1994). This questionnaire consists of 36 items related to work field. Responses were rated on a 6point scale ranging from 1 (disagree very) to 
6 (agree very much). High scores on the scale represent higher job satisfaction. The Cronbach's alpha for this study was 0.92 .

Organizational Commitment was measured using Meyer and Allen's (1990) scale. The questionnaire consists of 24 items related to employees' affective, continuance and normative aspects of the commitment to organization. Responses were rated on a 7-point scale ranging from 1 (strongly disagree) to 7 (strongly agree). The Cronbach's alpha for this study was 0.73 .

Work motivation was measured by using four questions related to enthusiasm, challenges etc. (Storseth, 2006). Responses were rated on a 5-point scale ranging from 1 (never) to 5 (always). The Cronbach's alpha for this study was 0.70 .

Employee turnover intentions were tapped by three item scale developed by H. L. Stallworth (2003). Responses were rated on a 7point scale ranging from 1 (strongly disagree) to 7 (strongly agree). The Cronbach's alpha for this study was 0.84 .

\section{Results}

The first part of the analysis consisted of bivariate correlations among personality attributes, work attitudes and turnover intentions. The results of the analysis yielded associations with personality and the work related attitudes under investigation. (see Table 1). Personality attributes of belonging- social interest and going along were positively related to work motivation and negatively to turnover intention $(p<0.05)$. Wanting recognition was found as significantly positively related to job satisfaction $(p<0.01)$. There was found significant positive relation between taking charge and job satisfaction as well as work motivation $(\mathrm{p}<0.05)$. Finally being cautious was negatively correlated with organizational commitment and work motivation but positively to turnover intention $(\mathrm{p}<0.01)$. There were significant inter-correlations among all work attitudes and turnover intention $(\mathrm{p}<0.000)$.

The results showed that personality attributes of belonging- social interest, going along,

\section{Table 1}

Bivariate correlations between Adlerian personality attributes, work attitudes and turnover intentions

\begin{tabular}{|c|c|c|c|c|c|c|c|c|c|c|c|}
\hline & & & 1. & 2. & 3. & 4. & 5. & 6. & 7. & 8. & 9 \\
\hline \multirow{2}{*}{$\begin{array}{l}1 . \\
2 .\end{array}$} & \multirow{5}{*}{ 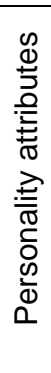 } & \begin{tabular}{l|} 
belonging- \\
social interest
\end{tabular} & 1.00 & & & & & & & & \\
\hline & & going along & $0.277^{* * *}$ & 1.00 & & & & & & & \\
\hline 3. & & taking charge & 0.136 & $-0.550^{\star * *}$ & 1.00 & & & & & & \\
\hline \multirow[t]{2}{*}{4.} & & $\begin{array}{l}\text { wanting } \\
\text { recognition }\end{array}$ & $0.426^{\star * *}$ & 0.074 & $0.324^{\star \star \star}$ & 1.00 & & & & & \\
\hline & & $\begin{array}{l}\text { being } \\
\text { cautious }\end{array}$ & $-0.514^{\star \star \star}$ & $-0.597^{* * *}$ & $0.200^{* *}$ & $-0.181^{*}$ & 1.00 & & & & \\
\hline 6. & \multirow{3}{*}{ 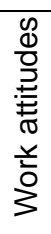 } & $\begin{array}{l}\text { job } \\
\text { satisfaction }\end{array}$ & 0.060 & -0.014 & $0.201^{*}$ & $0.163^{*}$ & $-0,093$ & 1.00 & & & \\
\hline 7. & & $\begin{array}{l}\text { organizational } \\
\text { commitment }\end{array}$ & 0.139 & 0.124 & -0.084 & 0.065 & $-0.219^{\star *}$ & $0.365^{\star * *}$ & 1.00 & & \\
\hline \multirow[t]{2}{*}{8.} & & $\begin{array}{l}\text { work } \\
\text { motivation }\end{array}$ & $0.243^{* *}$ & $0.155^{*}$ & 0.031 & $0.240^{* *}$ & $-0.226^{* *}$ & $0.353^{* * *}$ & $0.437^{* * *}$ & 1.00 & \\
\hline & & $\begin{array}{l}\text { turnover } \\
\text { intention }\end{array}$ & $-0.218^{* *}$ & $-0.277^{* * *}$ & 0.031 & -0.109 & $0.257^{\star \star \star}$ & $-0.343^{\star * *}$ & $-0.492^{\star \star *}$ & $-0.269^{\star \star * *}$ & 1.00 \\
\hline
\end{tabular}

Notes: significant correlations are shown in grey pattern

* $\quad$ significant at $p<0.05$

** $\quad$ significant at $p<0.01$

$* * * \quad$ significant at $p<0.001$ 
and wanting recognition were positively and being cautious- negatively related to work motivation $(\mathrm{p}<0.05)$. Taking charge and wanting recognition were positively related to organizational commitment $(p<0.05)$, but only being cautious was negatively related to job satisfaction $(\mathrm{p}<0.05)$. Bivariate correlation analysis revealed that some personality attributes were negatively (belonging- social interest and going along) and one (being cautious) positively related to turnover intentions of officers $(p<0.05)$.

Significant relations between work attitudes and turnover intentions were found as well. Results revealed that more satisfied, committed and motivated employees have low expressed intention to quit their job $(p<0.05)$.

A linear regression analysis with enter method was performed on the data set to determine the relationship of turnover intentions to work attitudes and lifestyle personality attributes. Several models were constructed. Regression analysis was conducted in order to check the predictive value of work attitudes to turnover intentions (see Table 2). The significance of the regression model was revealed $(R=0.59, F(3,126)=20.578, p<0.000)$.
The Regression model explained 34\% (R2) of the turnover intention variance. Two of three investigated work attitudes have the predictive value to turnover intention: lower organizational commitment $(\beta=-0.205, \mathrm{t}=-2.518$, $\mathrm{p}<0.05)$ and lower job satisfaction $(\beta=-0.387$, $\mathrm{t}=-4.55, \mathrm{p}<0.000)$. The predictive value of work motivation was not significant.

The predictive value of personality attributes to each of the work attitudes and turnover intention was explored. Coefficients of determination identified the questionable model - data fits (see Table 3). Contrary to our expectations Adlerian personality attributes contributed to the explanation of work attitudes among officers only with a minor predictive value: few of Adlerian personality attributes were identified as significant predictors for job satisfaction, but not for work motivation or organizational commitment. Being cautious was found as a significant negative predictor for job satisfaction $(\beta=-0.359, \mathrm{t}=-2.936, \mathrm{p}<0.001)$ and personality attribute of going along had a negatively tendency to predict job satisfaction $(\beta=-0.257, t=-1.887, p<0.1)$. There was detected a tendency, that personality attrib-

Table 2

$\boldsymbol{\beta}$ weights and $\mathrm{R}^{2}$ for model predicting turnover intention from work attitudes

\begin{tabular}{|c|c|c|}
\hline \multirow{2}{*}{ Work attitudes } & \multicolumn{2}{|c|}{ Predicting turnover intention } \\
\hline & B weight & t value \\
\hline Job satisfaction & -0.387 & $-4.550^{\star * *}$ \\
\hline $\begin{array}{l}\text { Organizational } \\
\text { commitment }\end{array}$ & -0.205 & $-2.518^{*}$ \\
\hline Work motivation & -0.133 & -1.604 \\
\hline \multicolumn{3}{|l|}{ Model fit indexes } \\
\hline$R$ & 0.578 & \\
\hline$R^{2}$ & 0,334 & \\
\hline$F$ & 20.578 & \\
\hline$p$ & 0.000 & \\
\hline
\end{tabular}

Notes: significant $p$ values are shown in bold

* $\quad$ significant at $p<0.05$

** significant at $p<0.01$

*** significant at $p<0.001$ 


\section{Table 3}

$\beta$ weights and $R^{2}$ for model predicting work attitudes (job satisfaction, organizational commitment and work motivation) and turnover intention from

Adlerian personality attributes

\begin{tabular}{|c|c|c|c|c|c|c|c|c|}
\hline \multirow{2}{*}{\begin{tabular}{|l|} 
\\
$\begin{array}{l}\text { Personality } \\
\text { attributes }\end{array}$
\end{tabular}} & \multicolumn{2}{|c|}{$\begin{array}{l}\text { Predicting job } \\
\text { satisfaction }\end{array}$} & \multicolumn{2}{|c|}{$\begin{array}{c}\text { Predicting } \\
\text { organizational } \\
\text { commitment }\end{array}$} & \multicolumn{2}{|c|}{$\begin{array}{l}\text { Predicting work } \\
\text { motivation }\end{array}$} & \multicolumn{2}{|c|}{$\begin{array}{l}\text { Predicting } \\
\text { turnover } \\
\text { intention }\end{array}$} \\
\hline & $\beta$ weight & t value & $\beta$ weight & $t$ value & $\beta$ weight & tvalue & $\beta$ weight & $t$ value \\
\hline $\begin{array}{l}\text { belonging- } \\
\text { social interest }\end{array}$ & 0.093 & 0.871 & -0.031 & -0.292 & 0.131 & 1.295 & -0.170 & $-1.689(t)$ \\
\hline going along & -0.257 & $-1.887(\mathrm{t})$ & -0.022 & -0.167 & 0.028 & 0.238 & -0.217 & $-1.875(t$ \\
\hline taking charge & -0.081 & -0.701 & 0.196 & 1.646 & 0.030 & $0.27 \oint$ & -0.145 & -1.351 \\
\hline $\begin{array}{l}\text { wanting } \\
\text { recognition }\end{array}$ & 0.067 & 0.622 & -0.004 & -038 & 0.107 & 1.087 & 0.084 & 0.865 \\
\hline being cautious & -0.359 & $-2.936^{\star *}$ & -0.119 & -1.020 & -0.115 & -1.074 & 0.063 & 0.597 \\
\hline \multicolumn{9}{|l|}{ Model fit indexes } \\
\hline$R$ & \multicolumn{2}{|c|}{0.324} & \multicolumn{2}{|c|}{0.198} & \multicolumn{2}{|c|}{0.290} & \multicolumn{2}{|c|}{0.302} \\
\hline$R^{2}$ & \multicolumn{2}{|c|}{0.105} & \multicolumn{2}{|c|}{0.039} & \multicolumn{2}{|c|}{0.084} & \multicolumn{2}{|c|}{0.091} \\
\hline$F$ & \multicolumn{2}{|c|}{2.947} & \multicolumn{2}{|c|}{1.082} & \multicolumn{2}{|c|}{2.853} & \multicolumn{2}{|c|}{3.094} \\
\hline$p$ & \multicolumn{2}{|c|}{0.015} & \multicolumn{2}{|c|}{0.373} & \multicolumn{2}{|c|}{0.017} & \multicolumn{2}{|c|}{0.011} \\
\hline
\end{tabular}

Notes: significant $p$ values are shown in bold

(t) tendency at $p<0.1$

* $\quad$ significant at $p<0.05$

** significant at $p<0.01$

*** significant at $p<0.001$

utes of belonging- social interest $(\beta=-0.170$, $\mathrm{t}=-1.698, \mathrm{p}<0.1)$ and going along $(\beta=-0.217$, $\mathrm{t}=-1.875, \mathrm{p}<0.1)$ could predict turnover intention $(R=0.302, F(5,159)=3.094, p<0.05)$.

One more regression model was created taking the complex of work attitudes and personality attributes as independent variables and turnover intention as the output (see Table 4). The goodness of fit of this model was better than previously constructed models $(\mathrm{R}=0.632, \mathrm{~F}(8,109)=8.409, \mathrm{p}<0,000)$. Current model could explain $40 \%$ (R2 = $0,400)$ variance of the turnover intention.

Finally the variables of age and work experience were added to the regression model in order to predict turnover intention. The model's prognostic value increased (see Table 5). It was the best model with the high- est prognostic value among the all constructed ones $(\mathrm{R} 2=0.430, \mathrm{R}=0.656,(\mathrm{~F}$ $(10,105)=7.110, p<0.000)$. Results revealed that more satisfied with their job, more committed to their organization and having higher expressed personality attribute of going along officers tend to leave their job more rarely.

\section{Discussion}

The purpose of the current study was to fit the Adlerian lifestyle personality attributes in relation to work motivation, job satisfaction, organizational commitment, and turnover intentions among officers.

Our findings supported some previous research which found the relations between work attitudes and intention to quit a job 


\section{Table 4}

$\beta$ weights and $\mathrm{R}^{2}$ for model predicting turnover intention from work attitudes (job satisfaction, organizational commitment and work motivation) and Adlerian personality attributes

\begin{tabular}{|c|c|c|c|}
\hline \multirow{2}{*}{\multicolumn{2}{|c|}{ Variables }} & \multicolumn{2}{|c|}{ Predicting turnover intention } \\
\hline & & $\beta$ weight & t value \\
\hline \multirow{3}{*}{ 亭 } & job satisfaction & -0.420 & $-4.305^{\star \star \star}$ \\
\hline & $\begin{array}{l}\text { organizational } \\
\text { commitment }\end{array}$ & -0.228 & $-2.539^{*}$ \\
\hline & work motivation & -0.068 & -0.756 \\
\hline \multirow{5}{*}{ 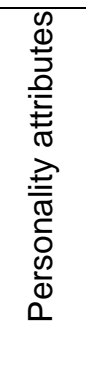 } & $\begin{array}{l}\text { belonging- social } \\
\text { interest }\end{array}$ & -0.075 & -0.778 \\
\hline & going along & -0.255 & $-1.972(\mathrm{t})$ \\
\hline & taking charge & -0.088 & -0.804 \\
\hline & $\begin{array}{l}\text { wanting } \\
\text { recognition }\end{array}$ & 0.108 & 1.096 \\
\hline & being cautious & -0.071 & -0.627 \\
\hline \\
\hline \multicolumn{4}{|c|}{ Model fit indexes } \\
\hline & $R^{2}$ & 0.400 & \\
\hline & $F$ & 8.409 & \\
\hline & $p$ & 0.000 & \\
\hline
\end{tabular}

Notes: significant $p$ values are shown in bold

( $t) \quad$ tendency at $p<0.1$

* $\quad$ significant at $p<0.05$

** significant at $p<0.01$

*** significant at $p<0.001$

(Labatmediene et al., 2007; Dowden and Tellier, 2004; Byrd et al., 2001; Byrd et al., 2000; Mynatt et al., 1997; Wright, 1993). Still only job satisfaction and organizational commitment had a predictive value to the officers' turnover intention, but not work motivation. Possible explanation is that work motivation might have a mediating role in between personality attributes and turnover: the same personality traits were found as related to both work motivation and intention to leave a job. Officers with higher expressed personality attributes of Belonging-Social Interest and Going Along are more motivated to their job and more rarely tend to leave their job. Results of this study supported some of the previous research related to the connection between social oriented personality at- tributes (previous studies- extraversion, current study- belonging- social interest) and work motivation among specific groups of professionals (Liesiene and Endriulaitiene, 2008; Jong et al. 2001). It shows that collaboration and following the rules is an important part in this type of organization, where the hierarchy levels are defined very clearly with the abilities to give and obey the instruction at the work.

Taking in consideration the costs of the frequent personnel turnover it would seem to make sense that any additional information related to work attitudes would be important to the organization. How ever this study did not shed additional information related to the dynamics the evolution of these work attitudes in this group under investigation. 
Table 5

$\beta$ weights and $\mathrm{R}^{2}$ for model predicting turnover intention from work attitudes (job satisfaction, organizational commitment and work motivation), Adlerian personality attributes and few demographic characteristics (age, work experience and work experience in a current position)

\begin{tabular}{|c|c|c|c|}
\hline \multirow{2}{*}{\multicolumn{2}{|c|}{ Variables }} & \multicolumn{2}{|c|}{ Predicting turnover intention } \\
\hline & & B weight & t value \\
\hline \multirow{3}{*}{ 喜营 } & job satisfaction & -0.422 & $-4.038^{\star \star \star}$ \\
\hline & $\begin{array}{l}\text { organizational } \\
\text { commitment }\end{array}$ & -0.195 & $-1.943(\mathrm{t})$ \\
\hline & work motivation & -0.092 & -0.974 \\
\hline \multirow{5}{*}{ 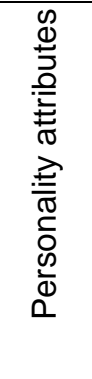 } & $\begin{array}{l}\text { belonging- social } \\
\text { interest }\end{array}$ & -0.043 & -0.412 \\
\hline & going along & -0.277 & $-2.028^{*}$ \\
\hline & taking charge & -0.117 & -1.013 \\
\hline & $\begin{array}{l}\text { wanting } \\
\text { recognition }\end{array}$ & 0.089 & 0.863 \\
\hline & being cautious & -0.078 & -0.630 \\
\hline \multirow{3}{*}{ 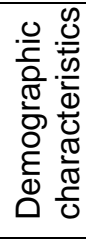 } & age & -0.299 & -1.485 \\
\hline & work experience & 0.169 & 0.797 \\
\hline & $\begin{array}{l}\text { work experience in } q \\
\text { current position }\end{array}$ & 0.111 & 1.033 \\
\hline \multicolumn{4}{|c|}{ Model fit indexes } \\
\hline \multicolumn{4}{|c|}{$\begin{array}{c}\text { Model tit indexes } \\
R\end{array}$} \\
\hline & $R^{2}$ & \multicolumn{2}{|l|}{0.430} \\
\hline & $F$ & \multicolumn{2}{|l|}{6.105} \\
\hline & $p$ & \multicolumn{2}{|l|}{0.000} \\
\hline
\end{tabular}

Notes: significant $p$ values are shown in bold

(t) tendency at $p<0.1$

* significant at $p<0.05$

** significant at $p<0.01$

*** significant at $p<0.001$

Many authors agree that person - job and person - organization fit is of primary importance (Amos and Weathington, 2008; McCulloch and Turban, 2007; Ehrhart, 2006; Westerman and Cyr, 2004; Rentsch and McEwen, 2002; Furnham, 2001).

Our study showed that the most important personality attributes for predicting lower job satisfaction among officers were the lifestyle personality attributes of Being Cautious and Going Along. It would make sense that employees with an elevated Being Cau- tious personality attribute would have difficulty in a setting that requires a person to work under such stressful and at times emotionally charged setting. Still it is not so easy to explain why officers with more expressed personality attribute of Going Along tend to be less satisfied with their job. The possible rationale for such a result might be the two sides of the organizations: very clear rules and requirements from one side (higher officers) of the organization and always unique situations from other side (prison- 
ers). This second side might lead to the fact that the possibility to work with low stress comes from flexibility and intention to find different ways of behavior and not from trying to fit the rules. These results might be of a value in selection process or better understanding of the work conditions and its' possible impact on the work attitudes among officers trying to decrease turnover.

Concerning organizational commitment only one of the investigated personality attributes- Being Cautious- was related to this work attitude. Importance of Being Cautious showed that sensitivity towards others is important when we deal with the officers' commitment to the organization. However a predictive value of Being Cautious for organizational commitment was not found. Such a result supported some previous ideas (Furnham et al., 2002; Koustelios, 2001; Griffin, 2001) that some organizational and situational factors (not personality) might be of the primary importance in the investigation of employees' work attitudes.

Contrary to some previous studies (Mynatt et al., 1997; Tett and Meyer, 1993; Mueller et al., 1992; Huselid and Day, 1991), however, we found that not only work attitudes but personality attributes were also directly related to turnover intentions. Our finding seem to support other researchers who believe that personality is in fact an important variable to address when assessing the work attitudes investigated in this study (Bowling, 2007; Tyler and Newcombe, 1996). On the other hand job satisfaction was found to be a good predictor of turnover intention in our study as well. Our results show that research that takes in consideration personality attributes, job satisfaction and turnover is still of a great value. Our research showed that there are different personality attributes related to job satisfaction and turnover intentions. Some of the personality traits might be linked to the more expressed intention to leave the job without exploring the level of job satisfaction: employees with higher expressed personality attributes of BelongingSocial interest and Going Along less tend to leave current work position. Other specific personality traits are related to the job satisfaction: officers with higher expressed attributes of Taking Charge and Wanting Recognition tend to be more satisfied with their job.

Finally our study seems to support research models that include a variety of variables such as personality, work attitudes, demographics, when attempting to explain turnover intentions. In fact such demographic characteristics of age and work experience were additive in predicting turnover intentions in the sample of correctional officers under investigation. Results of this study revealed that it is important to investigate demographic characteristics such as age and work experience, which might not have the direct predictive value to turnover intentions but usually are related to work attitudes (Kanfer and Ackerman, 2000, Woodard et al., 1994). More satisfied and committed officers with a higher expressed personality attribute of Going Along tend to leave their job more rarely. It means that personality attribute of Going Along is necessary for this type of organization where rules are strict and not flexible, the hierarchy is clearly described and employees don't have a lot of place for their own suggestions and decisions upon their work behavior. Still the fact that Going Along has a negative predictive value for both job satisfaction and turnover intention shows that there might be some related factors which were not investigated in this study but could have an important role in either job satisfaction or turnover. One of the possible factors related to the level of job satisfaction which we haven't investigated may be connected to the present economic conditions in Lithuania. Possibly though a employee is not satisfied with their job the fact that they have fewer options to move to another job may explain some of the contradictions in our findings. Turnover has decreased during the last months while the unemployment has increased which might have changed and possible is still changing the usual relations 
between personality attributes, work attitudes and turnover intentions. Investigation of these economical factors and how they might be related to the psychological aspects of employees work situation could be of a great value and give more clear view of the today's employees in the organization.

In retrospect, however, we believe that this research has the possibility of providing the next aspiring researcher to consider another theoretical model such as Individual Psychology to explain the interplay of personality, work attitudes and intentions to leave the job. In that this was the first study of it's kind one can and should consider some of the limitations of the study. We are acutely aware that instruments that are adapted for use in this study lack appropriate norms for Lithuania. We are also aware that the time required and the sequencing of the assessment instruments could have impacted results. We do hope that the study can encourage other researchers from Lithuania, Turkey, and other countries to continue the research begun in this study with the attempt to clarify more specifically the interrelatedness of lifestyle personality attributes, job satisfaction, biographical variables, work motivation, commitment and work force stability as it related to turnover and attrition.

\section{References}

Adler, A. (1969). The science of living. New York: Doubleday;

Allen, N.J., Meyer, J.P. (1990). The measurement and antecedents of affective, continuance and normative commitment to the organization. Journal of Occupational Psychology, 63:1-18.

Amos, E. A., and Weathington, B. L. (2008). An Analysis of the Relation between Employee-Organization Value Congruence and Employee Attitudes. The Journal of Psychology, 142(6): 615-631;

Ansbacher, H. L., and Ansbacher, R. R. (1956). The Individual Psychology of Alfred Adler New York: Harper \& Row;

Baard, P. P., Deci, E. L., and Ryan, R. M. (2004). Intrinsic Need Satisfaction: A Motivational Basis of Performance and Well-being in Two Work Settings. Journal of Applied Social Psychology, 34: 2045-2068;

Barrick, M. R., and Mount, M. K. (2005). Yes, Personality Matters: Moving on to More Important Matters. Human Performance, 18 (4): 359-372;

Biechekas, G., and Newlon, B. (1983). Life Style Analysis of Hospice Home Care Nurses. Individual Psychology, 39: 6670 ;

Bishay, A. (1996). Teacher Motivation and Job Satisfaction: A Study Employing the Experience Sampling Method. Journal of Undergraduate Science: Psychology, 3: 147-154;

Blickle, G., Schlegel, A., Fassbender, P., and Klein, U. (2006). Some Personality Correlates of Business White-Collar Crime. Applied Psychology: an International Review, 55(2): 220-233; 
Byrd, T. G., Cochran, J. K., Silverman, I. J., and Blount, W. R. (2000). Behind Bars: An Assessment of the Effects of Job Satisfaction, Job-related Stress, and Anxiety on Jail Employees' Inclinations to Quit. Journal of Crime and Justice, 23 (234): 69-93;

Bowling, N. (2007). Job Performance linked to Personality. Industrial Engineer: IE, 39(7): 11;

Carlson, C., Clemmer, F., Jennings, T., Thompson, C. D., and Page, L. J. (2007). Organizational development 101: Lessons from Star Wars. The Journal of Individual Psychology, 63(4): 424-439;

Carlson S. J., and Latta, R. M. (1980). The Effects of Gender and Attributions on Achievement Motivation and Subsequent Performance. [Internet approach: http://eric.ed.gov/ERICWebPortal/cu stom / portlets / recordDetails / detailmini.jsp?_nfpb=true\&_\&ERICExtSe arch_SearchValue_0=ED190921\&ERIC ExtSearch_SearchType_0=eric_accno\&a ccno=ED190921 ];

Castle, T. L. (2008). Satisfied in the Jail? Exploring the Predictors of Job Satisfaction among Jail Officers. Criminal Justice Review, 33(1): 48-63;

Catlin, J. (1984). Introducing Adierian psychology in industry: A training system approach. Chicago: Adler School of Professional Psychology;

Curlette, W. L., Wheeler, M. S., and Kern, R. M. (1993). BASIS-A Inventory interpretive manual: A psychological theory. Highlands, NC: TRT Associate;

Dowden, C., \& Tellier, C. (2004). Predicting work-related stress in correctional officers: A meta-analysis.Journal of Criminal Justice, Vol. 32, 31-47;
Ehrhart, K. H. (2006). Job Characteristic Beliefs and Personality as Antecedents of Subjective Person-Job Fit. Journal of Business and Psychology, 21(2): 193226;

Ferguson, E. D. (2007). Work Relations and Work Effectiveness: Goal Identification and Social Interest Can Be Learned. The Journal of Individual Psychology, 63(1): 110-117;

Ferguson, E. D. (2003). Work Relationships, Lifestyle, and Mutual Respect. Journal of Individual Psychology, 59(4): 501506;

Ferguson, E. D. (1996). Adierian principles and methods apply to workplace problems. The Journal of Individual Psychology, 52(3): 270-28;

Furnham, A. (2001). Vocational preference and p-o fit: reflections of Holland's theory of vocational choice. Applied Psychology: An International Review, 50(1): 1-25;

Furnham, A., Petrides, K. V., Jackson, C. J., and Cotter, T. (2002). Do Personality Factor Predict Job Satisfaction. Personality and Individual Differences, 33(8): 1325-1342;

Geneviciute-Janoniene, G., and Endriulaitiene, A. (2008). Relationship among Employee's Personality Traits and Work Motivation. Psichologija / Psychology, 38: 100-114;

Gentry, J.M., Winer, J.L., Sigelman, C. K., and Phillips, F. L. (1980). Adlerian lifestyle and vocational preference. Journal of Individual Psychology, 31(1): 80-86;

George, J. M., and Zhou, J. (2001). When Openness to experience and conscientiousness are related to creative behavior: An interactional approach, Journal of Applied Psychology , 86: 513-524; 
Griffin, M. L. (2001). Job Satisfaction among Detention Officers Assessing the Relative Contribution of Organizational Climate. Journal of Criminal Justice, 29(3): 219-232;

Hausknecht, J. P., Day, D. V., and Thomas, S. C. (2004). Applicant reactions to Selection Procedures: An Updated Model And Meta-Analysis. Personnel Psychology, 57: 639-683;

Jenkins, M., and Griffith, R. (2004). Using Personality Constructs to Predict Performance: Narrow or Broad Bandwidth. Journal of Business and Psychology, 19(2): 255-269;

Jong, R. D., Velde, M.E.G., \& Jansen, P.G.W. (2001). Openness to Experience and Growth Need Strengh as Moderators between Job Characteristics and Satisfaction. International Journal of Selection and Assessment, 9 (4);

Judge, T. A., and Ilies, R. (2002). Relationship of Personality to Performance Motivation: A Meta-Analytic Review. Journal of Applied Psychology, 87 (4): 797-807;

Judge, T. A., Bono, J. E., and Locke, E. A. (2000). Personality and Job Satisfaction: the mediating Role of Job Characteristics. Journal of Applied Psychology, 85(2): 237-249;

Kanfer, R., and Ackerman, P. L. (2000). Individual Differences in Work Motivation: Further Explorations of a Trait Framework. Applied Psychology: an international review, 49(3): 470-482;

Kepalaite, A., Endriulaitiene, A., and Liesiene, J. (2007). The Features of Adolescents' Vocational Types in the Frame of Individual Psychology. Educational Psychology: International Journal of Research on Educational Psychology, 18: 39-45;
Kern, R. M., Gormley, L., and Curlette, W. L. (2008). BASIS-A Inventory Empirical Studies: Research Findings from 2000 to 2006. The Journal of Individual Psychology, 64(3): 280-309;

Kern, R., and Peluso, P (1999). Using Individual Psychology concepts to compare family systems processes and organizational behavior. The Family Journal: Counseling and Therapy for Couples and Families, 7(3): 236-244;

Koustelios, A. D. (2001). Personal Characteristics and Job Satisfaction of Greek Teachers. International Journal of Educational Management, 15(7): 354-358;

Labatmediene, L., Endriulaitiene, A., and Gustainiene, L. (2007). Individual Correlates of Organizational Commitment and Intention to Leave the Organization. Baltic Journal of Management, 2(2): 196212;

Lambert, E. G., Reynolds, K. M., Paoline, E. A., and Watkins, R. C. (2004). The Effect of Occupational Stressors on Jail Staff Job Satisfaction. Journal of Crime and Justice, 27(1): 1-32;

Latham, G. P., and Pinder, C. C. (2005). Work Motivation Theory and research at the dawn of the twenty-first century. Annu Rev. Psychol, 56: 485-516;

Lee, K., Ashton, M. C., and Shin K. H. (2005). Personality Correlates of Workplace Anti-Social Behavior. Applied Psychology: an international review, 54(1): 81-98;

Lemonides, J. S. (2007). Toward an Adlerian Approach to Organizational Intervention. The Journal of Individual Psychology, 63(4): 399-413;

Liesiene, J., and Endriulaitiene, A. (2008). Biopsychosocial Correlates of Work Motivation. International Journal of Psychology: A Biopsychosocial Approach; 1: 15-28; 
Magner-Harris, J., Fiordan, R.J., Kern, R.M., and Curlette, W.L. (1979). Reliability of life style interpretations. Journal of Individual Psychology, 35(2): 196-202;

Magner-Harris, J., Riodan, R. J., and Kern, R. M. (1981). An Investigation of the Interjudge Agreement on a Subject's Vocational Choice and Life Style Type. Lifestyle: Theory, Practice, and Research, 2nd edition, Dubuque, IA, pp. 159-166;

McCulloch, M. C. \& Turban, D. B. (2007). Using Person-Organization Fit to Select Employees for High-Turnover Jobs. International Journal of Selection and Assessment, 15(1): 63-71;

Mount, M., Ilies, R., and Johnson, E. (2006). Relationship of Personality Traits and Counterproductive Work Behaviors: The Mediating Effects of Job Satisfaction. Personnel Psychology, 59: 591-622;

Mynatt, P. G., Omundson, J. S., Schroeder, R. G., and Stevens, M. B. (1997). The Impact of Anglo and Hispaic Ethnicity, Gender, Position, Personality and Job Satisfaction on Turnover Intentions: A Path Analytic Investigation. Critical Perspectives on Accounting, 8(6): 657683;

Neubert, S. P. (2004). The Five Factor Model of Personality in the Workplace, [Internet approach: http://www.personalityresearch.org/papers/naubert.html ];

Newlon, B. J., and Mansager, E. (1986). Adlerian Lifestyles among Catholic Priests. Individual Psychology, 42: 367374;

Ones, D. S., Viswesvaran, C., and Dilchert, S. (2005). Personality at Work: Raising Awareness and Correcting Misconceptions. Human Performance, 18(4): 389404;
Ortega, A., Brenner, S. O., and Leather, P. (2006). Occupational Stress, Coping and Personality in the Police: an SEM Study. International Journal of Police Science and Management, 9(1): 36-50;

Rentsch, J. R., and McEwen, A. H. (2002). Comparing Personality Characteristics, Values, and Goals as Antecedents of Organizational Attractiveness. International Journal of Selection and Assessment, 10(3): 225-234;

Spector, P.E. (1997). Job satisfaction: application, assessment, cause, and consequences. London: Sage;

Stallworth, H. L. (2003). Mentoring, organizational commitment and intentions to leave public accounting. Managerial Auditing Journal, 18(5): 405-18;

Stone, M. H. (2007). The Task of Work in Individual Psychology. The Journal of Individual Psychology, 63(1): 96-109;

Storseth, F. (2006). Changes at Work and Employee Reactions: Organizational elements, Job Insecurity, and Short-term Stress as Predictors for Employee Health and Safety. Scandinavian Journal of Psychology, 47: 541-550;

Suprina, J. S., and Lingle, J. A. (2008). Overcoming Societal Discouragement: Gay Recovering Alcoholics' Perceptions of the Adlerian Life Tasks. The Journal of Individual Psychology, 64(2): 193-212;

Sweiringa, M. (1989). Promoting cooperation in the workplace through Adierian principles. Chicago: Adler School of Professional Psychology;

Tyler, G. P., and Newcombe, P. A. (2006). Relationship between Work Performance and Personality Traits in Hong Kong Organizational Settings. International Journal of Selection and Assessment, 14(1): 37-50; 
Wasterman, J. W., and Cyr, L. A. (2004). An Integrative Analysis of Person- Organization Fit Theories. International Journal of Selection and Assessment, 12(3): 252-261;

Watkins, C. E. (1984). The Individual Psychology of Alfred Adler: Toward an Adlerian Vocational Theory. Journal of Vocational Behavior, 24: 28-47;

White, L. W. (2005). Workstyle and Lifestyle. The Journal of Individual Psychology, 61(1): 92-99;

Wood, R.E. \& Beckmann, N. (2006). Personality Architecture and FFM in Organzational Psychology. Applied Psychology: an International Review, 55(3): 453-469;

Woodard, G. M., Cassil, N., and Herr, D. (1994). The relationship between psychological climate and work motivation in a retail environment. Routledge: 297314;

Wright, T. A. (1993). Correctional employee turnover: A Longitudinal Study. Journal of Criminal Justice, 21: 131-142;

Yali, T., Xianjun, S., and Jianqiao, L. (2004). Grey Relational Analysis of Indicators for Recruiting Salespeople. The Journal of Grey System, 3: 285-290; 